\title{
Strategi Lembaga Amil Zakat dalam Meningkatkan Akses Sanitasi dan Air Bersih (Studi Kasus LAZ Harfa Serang)
}

\author{
Rika Yulita Amalia', Nurwahidin' ${ }^{2}$, Nurul Huda ${ }^{3}$ \\ ${ }^{1,2}$ Universitas Indonesia, Jakarta, Indonesia \\ ${ }^{3}$ Universitas YARSI, Jakarta, Indonesia \\ yulitarika@yahoo.com; nurwahidin@ui.ai.id; pakhuda@yahoo.com
}

\begin{abstract}
:Sustainable Development Goals (SDGs), which is a world development agenda, raised one of the issues that became the objectives of its achievement targets, namely related to sanitation and clean water. Various adverse effects can be caused by inadequate sanitation and clean water conditions, including diarrhea, stunting, and even death. Therefore, several parties are trying to overcome this problem, bearing in mind the condition of sanitation and clean water in Indonesia still needs more attention. One of the parties concerned about the sanitation and clean water conditions is the Amil Zakat Harapan Duafa Institute (LAZ Harfa) Serang, Banten. LAZ Harfa has succeeded in changing the behavior of around 50,000 people who previously had open defecation habits to become accustomed to defecating in their place. This paper aims to find out the strategies carried out by LAZ Harfa so that it can succeed in carrying out the program. The method used in this study is a semi-structured interview with related parties. The results showed that the main strategy of LAZ Harfa in carrying out the sanitation and clean water program was by conducting education, optimizing the role of facilitator facilitators, cooperating, engaging the community directly, and cooperating with various partners.
\end{abstract}

Keywords $\quad$ : SDGs, Sanitation, Clean Water, Amil Zakat Institutions

\section{Latar Belakang}

Sanitasi dan Air bersih merupakan salah satu isu penting yang diangkat dalam agenda pembangunan dunia atau dikenal dengan istilah Sustainable Development Goals (SDGs). Isu sanitasi dan air bersih tersebut terdapat pada poin nomor enam dalam SDGs yaitu menyerukan sanitasi dan air bersih yang memadai serta merata untuk semua kalangan. Pentingnya menyerukan sanitasi dan air bersih untuk semua kalangan dikarenakan terdapat dampak buruk yang dapat ditimbulkan akibat tidak layaknya akses sanitasi dan air bersih.

Beberapa penelitian terdahulu telah mengungkap bagaimana sanitasi dan air bersih berdampak buruk pada kesehatan. Penelitian yang dilakukan oleh Cronin et al. (2016) menyebutkan bahwa tempat pembuangan kotoran besar yang terbuka erat kaitannya dengan peningkatan kemungkinan diare pada anak. Hal serupa juga dinyatakan dalam penelitian yang dilakukan oleh Otsuka et al. (2019) bahwa anak-anak dari rumah tangga yang menggunakan tempat penyimpanan air yang terbuka mempunyai resiko diare yang lebih tinggi dibanding anak dari rumah tangga yang menggunakan wadah tertutup untuk menyimpan air. Bahkan Fink et al. (2011) menyebutkan dalam penelitiannya bahwa akses sanitasi yang lebih baik erat kaitannya dengan resiko kematian yang lebih rendah. 
Selain diare, sanitasi dan air bersih yang tidak layak juga dapat menyebabkan stunting atau kerdil. Israul \& Hera (2018) menjelaskan bahwa anak-anak dibawah 5 tahun yang tinggal di sebuah rumah dengan sanitasi yang kurang memadai memiliki resiko stunting 0,64 kali lebih tinggi daripada anak-anak yang tinggal di rumah dengan sanitasi yang layak. Selain itu anak-anak yang hidup didaerah dengan kualitas air tidak layak memiliki kemungkinan stunting 0,87 kali lebih tinggi.

Selanjutnya sanitasi dan air bersih juga erat kaitannya dengan Indeks Pembangunan Manusia (IPM). Kustanto (2015) menyebutkan bahwa peningkatan kelayakan sanitasi dan akses air minum di tingkat individu, rumah tangga serta masyarakat dapat menurunkan angka berbasis masyarakat juga dapat meningkatkan angka harapan hidup. Hal tersebut secara tidak langsung akan mempengaruhi IPM, karena dalam menghitung IPM terdapat komponen angka harapan hidup. Riahi et al. (2018) menyebutkan bahwa kematian yang diakibatkan diare mempunyai hubungan yang signifikan dengan IPM.

Sanitasi dan air bersih yang buruk tidak hanya berpengaruh pada aspek kesehatan, namun juga dapat berdampak buruk pada aspek Ekonomi. Kerugian ekonomi yang diakibatkan sanitasi buruk mencapai 56 Triliun/Tahun. Kerugian tersebut termasuk hilangnya pendapatan karena tidak masuk kerja, menurunnya kunjungan wisatawan, biaya pengobatan serta pengolahan air baku (Prabowo et al., 2016). Selain itu, sanitasi dan air bersih yang buruk juga menyumbang kerugian sebesar 2.3\% dari PDB Indonesia. Banyaknya dampak buruk yang diakibatkan oleh sanitasi dan air bersih yang tidak layak menjadikan isu sanitasi dan air bersih tidak boleh diabaikan.

Di Indonesia, sanitasi dan air bersih yang layak belum mencapai 100\%. Padahal dalam Rencana Pembangunan Jangka Menengah Nasional (RPJMN) disebutkan bahwa target akses sanitasi dan air bersih pada tahun 2019 mencapai 100\%. Berdasarkan data yang dirilis oleh Badan Pusat Statistik (BPS), persentase Rumah Tangga yang memiliki akses sanitasi layak di Indonesia pada tahun 2017 baru mencapai $67.89 \%$. Artinya bahwa $32.11 \%$ rumah tangga di Indonesia tidak memiliki akses sanitasi yang layak. Adapun Rumah Tangga yang mempunyai akses sanitasi dan air bersih selama 4 tahun terakhir adalah sebagai berikut:

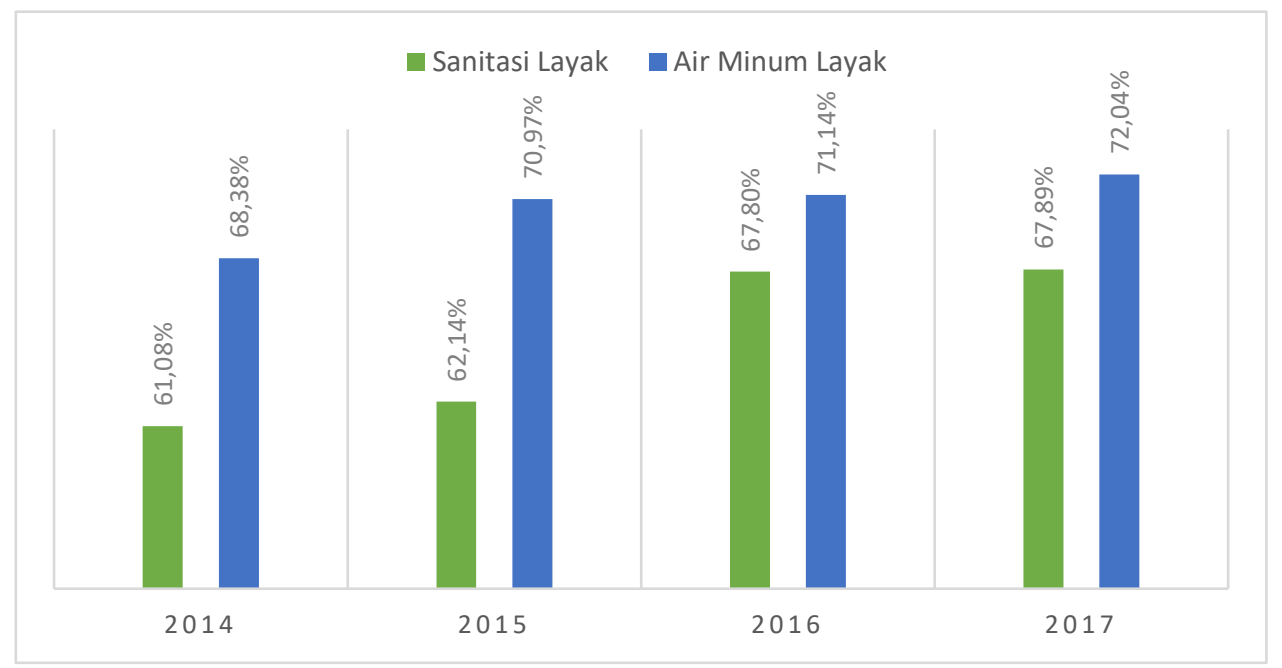

Gambar 1 Persentase Rumah Tangga yang mempunyai akses Sanitasi dan Air Bersih di Indonesia

Sumber: Badan Pusat Statistik

Salah satu penyumbang angka sanitasi yang tidak layak adalah didaerah pedesaan khususnya daerah terpencil. Misalnya, dilansir dari merdeka.com bahwa terdapat temuan 
Dinas Kesehatan Kota Serang yang menyebutkan bahwa masalah BAB sembarangan yang dilakukan masyarakat di 63 Kelurahan yang berada di 6 Kecamatan di Provinsi banten masih cukup tinggi. Diantaranya di Kelurahan Pasuluhan Kecamatan Walantaka yang warganya memiliki jamban hanya sekitar 30,32\%. Kemudian warga yang memiliki jamban di Kelurahan Sukawan Kecamatan Serang hanya sekitar 30,59\%.

Kondisi sanitasi dan air bersih di Indonesia yang masih membutuhkan perhatian lebih membuat berbagai pihak berupaya untuk mengatasi permasalahan tersebut. Diantaranya adalah Program Penyediaan Air Minum dan Sanitasi Berbasis Masyarakat (PAMSIMAS), Program hibah Air Minum yang dilakukan oleh Kementrian Pekerjaan Umum dan Perumahan Rakyat (PUPR) serta program Sanitasi Total Berbasis Masyarakat (STBM) yang merupakan program pemicuan untuk merubah perilaku higiene dan sanitasi masyarakat yang dilakukan oleh Kementerian Kesehatan. Selain pemerintah, berbagai lembaga swasta juga melakukan program serupa seperti program water credit yang merupakan kredit mikro melalui lembaga keuangan untuk meningkatkan sarana prasarana sanitasi dan air bersih. Selain itu Koperasi Syariah (Kopsyah) Benteng Mikro Indonesia (BMI) juga mempunyai skema pembiayaan mikro untuk meningkatkan akses terhadap sanitasi yang aman untuk masyarakat miskin serta lembaga lainnya, namun yang menarik diantara berbagai pihak yang melakukan upaya untuk meningkatkan akses sanitasi dan air bersih tersebut adalah adanya Lembaga Amil Zakat yang berhasil meningkatkan akses sanitasi dan air bersih masyarakat tanpa sedikitpun dana yang dikeluarkan, disamping menggunakan dana zakat, infak, sedekah dan wakaf (ZISWAF) bagi masyarakat yang benar-benar membutuhkan. Lembaga Amil Zakat tersebut adalah Lembaga Amil Zakat Harapan Duafa (LAZ Harfa).

LAZ Harfa (Lembaga Amil Zakat Harapan Duafa) merupakan salah satu lembaga amil zakat yang ada di Indonesia khususnya terletak di kota Serang, Provinsi Banten. Salah satu program pemberdayaan yang menjadi fokus LAZ Harfa adalah terkait sanitasi dan air bersih. Dilansir dari kabar-banten.com, diketahui bahwa LAZ Harfa mendapatkan dua penghargaan tingkat nasional pada tahun 2018 karena keberhasilan berbagai programnya. Penghargaan tersebut yaitu BAZNAS Award kategori pendistribusian terbaik serta terpilih sebagai juara pertama unggulan model pemberdayaan sosial melalui optimalisasi Zakat, Infak, Sedekah, Wakaf (ZISWAF) pada acara Festival Ekonomi Syariah Regional Jawa. Disamping itu, LAZ Harfa juga berhasil mengubah 50.000 pola pikir masyarakat Pandeglang terkait kebiasaan BAB sembarangan. Oleh karena itu lah penulis tertarik menjadikan LAZ Harfa sebagai subjek penelitian.

Fokus pada penelitian ini adalah untuk mengetahui bagaimana strategi LAZ Harfa dalam mengubah pola pikir masyarakat untuk tidak Buang Air Besar sembarangan. Penelitian ini berbeda dengan penelitian sebelumnya pada subjek, metode serta output penelitian. Dimana pada penelitian sebelumnya, program sanitasi dan air bersih yang diteliti atau diangkat adalah program bantuan sarana sanitasi dan air bersih dari hibah pemerintah atau lembaga swasta lainnya dengan skema kredit.

Penelitian ini diharapkan mampu memberikan gambaran terkait strategi pemberdayaan masyarakat untuk akses sanitasi dan air bersih. Selain itu, diharapkan pula penelitian ini dapat dijadikan rujukan untuk praktisi maupun akademisi untuk strategi proyek yang berkaitan ataupun sebagai referensi penelitian selanjutnya. 


\section{Teori dan Metode}

\subsection{Sanitasi dan Air Bersih}

Mara et al. (2010) mendefinisikan sanitasi sebagai pembuangan kotoran manusia yang aman, dimana manusia harus mengeluarkan kotorannya secara higienis untuk menghindari dampak negatif terhadap kesehatan dirinya sendiri maupun orang lain. Pengertian sanitasi menurut World Health Organization (WHO) adalah suatu usaha yang mengawasi beberapa faktor lingkungan fisik yang mempunyai pengaruh kepada manusia terutama pengaruh terhadap kesehatan, perkembangan fisik serta kelangsungan hidup manusia. Adapun pengertian sanitasi menurut Keputusan Menteri Kesehatan Republik Indonesia nomor: 965/MENKES/SK/XI/1992 adalah upaya untuk mewujudkan kondisi yang memenuhi persyaratan untuk kesehatan. Tujuan adanya sistem sanitasi diantaranya adalah untuk melindungi kesehatan manusia, meninimalisir adanya degradasi lingkungan serta penipisan sumber daya dan mempertahankan penerimaan sosial dalam jangka panjang (Lapid, 2012).

Air bersih merupakan salah satu kebutuhan dasar dan vital bagi manusia. Dimana air digunakan untuk segala aktivitas manusia seperti minum, memasak, mencuci, mandi serta sanitasi. Air yang dapat digunakan untuk kegiatan sehari-hari tersebut merupakan air bersih, yaitu air yang layak untuk dijadikan air baku bagi air minum. Adapun berdasarkan Peraturan Menteri Kesehatan RI No. 416/MENKES/PER/IX/1990 tentang syarat-syarat pengawasan kualitas air, air bersih merupakan air yang dapat digunakan untuk keperluan sehari-hari yang kualitasnya memenuhi syarat kesehatan dan dapat diminum apabila telah dimasak. Selanjutnya, air minum yang aman bagi kesehatan apabila telah memenuhi persyaratan fisika, mikrobiologi, kimiawi dan radioaktif. Utami \& Handayani (2017) menyebutkan bahwa ketersediaan air bersih menjadi salah satu penentu kualitas hidup suatu masyarakat. Hal tersebut dikarenakan ketersediaan air dapat mempengaruhi berbagai sektor termasuk kesehatan dan ekonomi.

Adapun dalam ajaran Islam, sanitasi dan air bersih merupakan aspek penting yang perlu diperhatikan karena berkaitan erat dengan masalah kebersihan. Bahkan dalam Islam, pentingnya kebersihan tersebut disebutkan dalam Al-Qur'an bahwa Allah menyukai orangorang yang menjaga kebersihan:

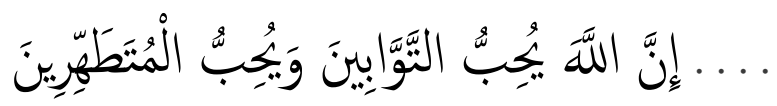

Artinya: "Sesungguhnya Allah menyukai orang-orang yang bertaubat dan menyukai orang-orang yang menyucikan diri”. (Q.S Al-Baqarah: 222)

\subsection{Lembaga Amil Zakat}

Berdasarkan Undang-Undang nomor 23 tahun 2011 tentang Pengelolaan Zakat, yang dimaksud dengan Lembaga Amil Zakat atau disingkat dengan LAZ merupakan lembaga yang dibentuk oleh masyarakat serta memiliki tugas untuk membantu dalam pengumpulan, pendistribusian dan pendayagunaan zakat. Secara umum, di Indonesia terdapat dua jenis Lembaga Pengelola Zakat yaitu Badan Amil Zakat Nasional (BAZNAS) dan Lembaga Amil Zakat (LAZ). Perbedaan keduanya adalah BAZNAS merupakan Badan Amil Zakat yang didirikan oleh pemerintah, berkedudukan sebagai Lembaga Pemerintah non struktural, sedangkan Lembaga Amil Zakat atau LAZ merupakan Lembaga yang dibentuk oleh masyarakat. Selain itu, terdapat pula Unit Pengumpul Zakat (UPZ) yang merupakan satuan organisasi yang dibentuk oleh BAZNAS untuk membantu pengumpulan zakat. 
Salah satu hal yang mendasari lahirnya Lembaga Amil Zakat (LAZ) adalah adanya dukungan pemerintah melalui Keputusan Menteri Sosial Nomor 19 Tahun 1998 yang memberi wewenang kepada masyarakat yang melakukan pelayanan kesejahteraan bagi kaum fakir miskin melalui pengumpulan serta penyaluran zakat, infak dan sedekah (Syafiq, 2016). Pada mulanya, peraturan terkait pengelolaan zakat diatur dalam Undang-Undang Nomor 38 Tahun 1999 tentang Pengelolaan Zakat yang kemudian ditindak lanjuti dengan adanya keputusan Menteri Agama Tahun 1999 tentang Pelaksanaan UU Pengelolaan Zakat serta Keputusan Dirjen Bimas Islam dan Urusan Haji Nomor D/291 Tahun 2000 tentang Pedoman Teknis Pengelolaan Zakat. Adanya peraturan-peraturan tersebut mendorong masyarakat untuk mendirikan Lembaga Amil Zakat.

\subsection{Ziswaf untuk Sanitasi dan Air Bersih di Indonesia}

Isu sanitasi dan air bersih mempunyai perhatian cukup besar dari berbagai institusi di Indonesia. Pada tahun 2015, Majelis Ulama Indonesia (MUI) mengeluarkan fatwa nomor 001/MUNAS-IX/MUI/2015 terkait pendayagunaan harta zakat, infak, sedekah dan wakaf untuk pembangunan sarana air bersih dan sanitasi bagi masyarakat Indonesia. Bahkan dalam fatwa tersebut juga dijelaskan bahwa MUI merekomendasikan kepada Lembaga Amil Zakat di Indonesia terkait pendistribusian zakat dalam penyediaan sarana dan air bersih guna menjawab kebutuhan masyarakat. Dukungan terhadap isu sanitasi dan air bersih diperkuat dengan adanya kesepakatan berupa $\mathrm{MoU}$ antara Bappenas (Badan Perencanaan Pembangunan Nasional), BAZNAS (Badan Amil Zakat Nasional), BWI (Badan Wakaf Indonesia) dan MUI (Majelis Ulama Indonesia) dalam memberikan dukungan program Air Bersih dan Sanitasi sebagai upaya untuk mewujudkan tujuan SDGs terkait Sanitasi dan air bersih.

Selain itu, pada bulan agustus 2019, Badan Amil Zakat Nasional (BAZNAS) menerbitkan pengembangan indeks untuk keberlanjutan Air Bersih dan Sanitasi atau BAZNAS Index for Sustainable Water and Sanitation (BI-WAS). Indeks tersebut merupakan alat ukur keadaan air dan sanitasi suatu daerah, output nya merupakan rekomendasi yang akurat bagi pelaksanaan program sanitasi dan air bersih bagi lembaga-lembaga pelaksana, BAZNAS maupun pemerintah terkait. Alat ukur yang dikembangkan tersebut juga sebagai upaya harmonisasi program BAZNAS terkait sanitasi dan air bersih dengan kampanye global SDGs ke enam (Puskas BAZNAS, 2019). Hal tersebut menunjukan bahwa selain isu ekonomi, institusi zakat di Indonesia juga ikut memperhatikan dan mendukung isu kesehatan lingkungan dalam hal ini sanitasi dan air bersih, dimana sanitasi dan air bersih tersebut merupakan aspek yang sangat penting dalam kehidupan manusia.

\subsection{LAZ Harfa}

Lembaga Amil Zakat (LAZ) Harfa merupakan Lembaga Amil Zakat Skala Provinsi yang menghimpun dana sosial seperti Zakat, Infak, Sedekah, Wakaf dan Fidyah (ZISWAF). Selain itu, LAZ Harfa juga menghimpun dana Hibah atau CSR dari donatur perorangan, komunitas maupun lembaga atau perusahaan (lazharfa.org). LAZ Harfa berdiri pada tanggal 25 September 2014 yang merupakan fusi dari empat LAZ yang berada di kabupaten dan kota yaitu LAZ Harapan Umat (LAZ HaRum), Lembaga Yatim Duafa (Latifa) serta LAZ Dompet Amanah Amal Insani (DAAI). Semua LAZ tersebut difusikan karena LAZ yang diakui oleh pemerintah merupakan LAZ yang berada pada tingkat provinsi dan pusat.

Visi LAZ Harfa adalah menjadi lembaga terpercaya dalam pemberdayaan Duafa, sehingga misinya adalah membangun partisipasi serta kepedulian masyarakat terhadap kaum Duafa, mengelola ZISWAF serta dana lainnya untuk meningkatkan kesejahteraan 
masyarakat dan membangun potensi masyarakat melalui kemitraan dengan perusahaan, pemerintah dan NonGovernment Organization (NGO).

Adapun program-program LAZ Harfa diantaranya adalah:

1. Program Pemberdayaan Zakat Infak Sedekah (ZIS) LAZ Harfa yang diwujudkan melalui aksi-aksi kongkrit dimana manfaatnya dapat dirasakan oleh masyarakat. Aksi-aksi tersebut diantaranya:

a. Aksi Peduli Cerdas yang fokus di bidang pendidikan diantaranya menyelenggarakan pendidikan kesetaraan, memberikan beasiswa prestasi untuk yatim dan Duafa, memberikan kursus menjahit gratis di LKP Harfa Skill Center, mengadakan program santunan bagi guru ngaji di kampung serta mendirikan Pondok Generasi Harapan untuk membina anak-anak yatim dan Duafa di bidang tahfidz Al-Qur'an dan entrepreneur

b. Aksi Peduli Sehat yang fokus di bidang kesehatan. Diantara program aksi peduli sehat adalah kegiatan pos layanan kesehatan gratis, kegiatan khitanan massal untuk anak-anak Duafa, program kesehatan lingkungan, Bantuan Sarana Air Bersih (SAB), Promosi Kesehatan (Promkes), Community Lead Total Sanitation (CLTS) yaitu pembuatan jamban tanpa subsidi serta sekolah hijau.

c. Aksi Peduli Ekonomi yang merupakan aksi yang fokus di bidang ekonomi diantaranya adalah Bantuan Dana Bergulir yang merupakan bantuan modal usaha, melakukan pembinaan kelompok ekonomi mikro dan koperasi keuangan mikro berbasis perempuan, program ternak berkah dan program tani berkah.

d. Aksi Peduli Sosial diantaranya berupa bantuan penuh untuk anak yatim sebagai anak asuh LAZ Harfa, program sentuhan hati mualaf yang merupakan bantuan produktif untuk mualaf, bantuan kaki palsu untuk masyarakat difabel, program desiminasi perlindungan anak dan kesetaraan gender dan program tebar qurban dan aqiqah di kampung Duafa.

e. Aksi peduli Kemanusiaan yang merupakan aksi tanggap darurat bencana di Indonesia serta di negara-negara lainnya yang dilanda bencana dan peperangan seperti Palestina, Rohingya, Mesir dll. Dalam melaksanakan program aksi peduli kemanusiaan tersebut LAZ Harfa bekerjasama dengan lembaga-lembaga kemanusiaan lainnya.

2. Program Kemitraan

LAZ Harfa juga membangun kerjasama dan kemitraan dengan pemerintah maupun swasta untuk merealisasikan program-programnya. Diantara program kemitraan tersebut adalah:

1. kerjasama dengan Universitas Indonesia dalam program Bank Sampah

2. Penyaluran Qurban serta tanggap darurat bencana banjir dengan PKPU, Rumah Zakat (RZ), Aksi Cepat Tanggap (ACT) dan Dompet Duafa

3. Kerjasama dengan komunitas Al-Ikhlas Tangerang dan PT Panca Pastika Mandiri dalam pembangunan Madrasah Diniah Pasirkadu 2016 dan lain-lain.

Selain itu, LAZ Harfa juga memiliki beberapa desa dampingan.

\subsection{Metode Penelitian}

Metode yang digunakan dalam penelitian ini adalah deskriptif kualitatif, yaitu analisis data yang dilakukan secara bersamaan dengan pengumpulan data. Sementara itu, proses analisis data pada penelitian ini bersifat induktif yaitu mengumpulkan informasiinformasi khusus menjadi satu kesatuan dengan mengumpulkan data, menyusun, mengklasifikasikan serta menganalisa strategi LAZ Harfa dalam menjalankan program sanitasi dan air bersih (Wiradifa \& Saharuddin, 2017). 
Data yang digunakan merupakan data primer yang diambil melalui wawancara mendalam dan terstruktur kepada pihak yang bersangkutan, yaitu direktur LAZ Harfa (I.Prihanande). Selain itu, digunakan pula data sekunder yang diambil dari berbagai literatur seperti buku, makalah, website, annual report dll.

\section{Hasil dan Pembahasan}

\subsection{Program Sanitasi dan Air Bersih LAZ Harfa}

Salah satu latarbelakang adanya program sanitasi dan air bersih oleh LAZ Harfa adalah kondisi masyarakat di Banten, khususnya daerah Pandeglang yang masih banyak melakukan Buang Air Besar sembarangan di tempat terbuka. Selain itu, berdasarkan hasil wawancara, permasalahan tersebut juga muncul karena setelah kurang lebih sekitar tiga belas tahun LAZ Harfa melakukan pemberdayaan, kemasyarakatan, ternyata persoalan di masyarakat tidak hanya terkait kesejahteraan saja. Namun ada hal yang lebih penting dan utama yaitu kesehatan. Hal tersebut dikarenakan sekuat apapun perekonomian yang akan dibangun, namun ketika masalah kesehatan tidak terselesaikan maka perekonomian tersebut akan goyah karena alokasi dana akan habis untuk kesehatan. Hal tersebut sejalan dengan pernyataan Rizki \& Saleh (2007) bahwa pembangunan dan perbaikan bidang sanitasi secara tidak langsung akan mengurangi kemiskinan.

Program pemberdayaan sanitasi dan air bersih yang dilakukan oleh LAZ Harfa diantaranya adalah Program Pembangunan Sarana Air Bersih (SAB) dan program pembangunan jamban yang melibatkan partisipasi masyarakat serta tanpa subsidi melalui pendekatan Community Lead Total Sanitation (CLTS). Program-program tersebut adalah program yang menitikberatan pada penyadaran masyarakat akan pentingnya sarana pembuangan air besar untuk kesehatan pribadi dan lingkungan. Selain itu, ada pula program Promosi Kesehatan (Promkes) seperti Hygiene, Nutrisi dan Cuci Tangan pakai Sabun. Program-program tersebut merupakan bentuk kepedulian LAZ Harfa sebagai lembaga sosial kemanusiaan terhadap kondisi lingkungan sekitarnya.

\subsection{Strategi Pelaksanaan Program Sanitasi dan Air Bersih LAZ Harfa}

Strategi adalah istilah yang digunakan dalam membentuk sistematika yang perlu dibangun dalam pengelolaan suatu organisasi (Chaniago, 2014). Selain itu, strategi juga pada dasarnya merupakan seni serta ilmu untuk menggunakan juga mengembangkan kekuatan untuk mencapai tujuan yang telah ditetapkan sebelumnya. LAZ Harfa sebagai suatu organisasi berbentuk lembaga juga memerlukan strategi sebagai acuan dalam melaksanakan berbagai programnya. Dimana strategi yang dibentuk tersebut harus berdasarkan visi dan misi organisasi yang berlandaskan ajaran Islam, mengingat LAZ Harfa merupakan Lembaga Amil Zakat yang kental dengan misi Islam.

Dalam menjalankan program pemberdayaan sanitasi dan air bersih, diperlukan strategi yang efektif dan tepat agar pola pikir serta kebiasaan masyarakat dapat berubah menjadi lebih baik. Berdasarkan program-program sanitasi dan air bersih yang telah dilakukan beberapa pihak sebelumnya, ditemukan beberapa permasalahan dalam pemberdayaan program tersebut diantaranya adalah sarana prasarana sanitasi dan air bersih yang merupakan bantuan beberapa diantaranya terbengkalai dan menjadi gudang karena kurangnya kepedulian masyarakat untuk menjaga sarana prasarana sanitasi dan air bersih tersebut. Selain itu kebiasaan dan pengetahuan masyarakat terhadap sanitasi dan air bersih yang masih perlu banyak diperbaiki (Wardiha \& Putri, 2018). Sehingga seringkali masyarakat yang telah menerima program bantuan kembali melakukan kebiasaan lamanya 
yaitu BABS. Oleh karena itu, LAZ Harfa berupaya untuk menjalankan program sanitasi dan air bersih yang efektif serta menyelesaikan permasalahan tersebut hingga akarnya.

Berdasarkan hasil wawancara penulis dengan pihak yang berkaitan. Beberapa strategi yang dilakukan oleh LAZ Harfa terhadap program sanitasi dan air bersih diantaranya adalah:

1. Melakukan pola-pola edukasi dalam mengubah pola pikir masyarakat.

Salah satu strategi yang dilakukan oleh LAZ Harfa dalam meningkatkan akses sanitasi dan air bersih bagi masyarakat adalah melalui pola edukasi serta pemicuan untuk mengubah pola pikir masyarakat. Karena salah satu hal yang menjadi permasalahan utama terkait sanitasi dan air bersih adalah pola pikir masyarakat serta budaya atau kebiasaan BAB sembarangan yang turun temurun. Sehingga ketika pola pikir masyarakat terkait sanitasi dan air bersih tersebut belum berubah, maka ada kemungkinan di kemudian hari kebiasaan tersebut akan terulang kembali.

Ketika pola pikir serta perilaku masyarakat telah berubah, maka kapanpun dan dimanapun, masyarakat akan tetap terjaga perilakunya dalam hal ini perilaku terkait sanitasi dan air bersih.

Oleh karena itu, edukasi yang intens terkait sanitasi dan air bersih untuk mengubah pola pikir masyarakat sangat diperlukan. LAZ Harfa menggunakan pendekatan kesehatan serta agama dalam mengedukasi masyarakatnya. Selain itu, LAZ Harfa juga memberikan edukasi dan promosi terkait sanitasi dan air bersih kepada sekolahsekolah dan lembaga pendidikan lainnya.

2. Melibatkan masyarakat secara langsung

Pola pemberdayaan masyarakat yang dilakukan oleh LAZ Harfa merupakan pola yang melibatkan masyarakat secara langsung. Maksud dari melibatkan masyarakat secara langsung adalah masyarakat dilibatkan secara langsung dalam proses pendanaan serta pembangunan serta pemeliharaan sarana dan prasarana sanitasi dan air bersih itu sendiri. Sehingga sarana yang telah dibangun lebih terawat dan tidak terbengkalai.

Dengan adanya keterlibatan masyarakat secara langsung tersebut dapat menimbulkan rasa tanggung jawab dan meningkatkan kepedulian satu sama lain. Sehingga program tersebut meningkatkan potensi keberlanjutan.

3. Menerapkan Prinsip Gotong-Royong

Program sanitasi dan air bersih yang dilakukan oleh LAZ Harfa menerapkan strategi gotong-royong dengan dibuatnya kelompok-kelompok kecil. Artinya, pembangunan sarana sanitasi dan air bersih dilakukan per-kelompok dan bergotong royong saling membangun dengan uangnya masing-masing atau sesuai dengan kesepakatan masyarakat tersebut atau dapat pula dikatakan dengan membangun pola arisan. Sehingga seringkali LAZ Harfa tidak perlu mengeluarkan uang sedikitpun untuk pembangunan jamban tersebut karena pembangunan jamban lahir dari kesadaran masyarakatnya sendiri setelah adanya perubahan pola pikir.

Adapun untuk masyarakat dengan kondisi tertentu, misalnya janda atau yang tidak mampu, LAZ Harfa mendorong masyarakat lain untuk saling membantu agar semua masyarakat mempunyai akses yang sama. 
4. Optimalisasi peran Fasilitator

Strategi selanjutnya adalah optimalisasi peran fasilitator. Berdasarkan pengalaman sebelumnya, peran fasilitator sangat diperlukan dalam memantau, mendampingi serta mengajak masyarakat untuk mengubah perilaku nya terkait sanitasi dan air bersih. Bahkan tenaga amil zakat LAZ Harfa didistribusikan ke berbagai daerah sasaran program untuk tinggal 24 jam selama lima hari bersama masyarakat. Hal tersebut dilakukan untuk membangun kedekatan dengan masyarakat sehingga proses pendampingan dan pelaksanaan program dapat berjalan optimal.

5. Melakukan kerjasama dengan berbagai Mitra

Strategi selanjutnya adalah kerjasama dengan berbagai mitra. LAZ Harfa membuka kesempatan selebar-lebarnya terhadap berbagai mitra yang ingin melakukan kerjasama dengan LAZ Harfa khususnya dalam hal ini adalah terkait sanitasi dan air bersih. Adanya kolaborasi LAZ Harfa dengan berbagai mitra tersebut diharapkan dapat mengoptimalkan akses sanitasi dan air bersih yang layak untuk semua kalangan.

Adapun beberapa program kerjasama LAZ Harfa dengan berbagai mitra terkait sanitasi dan air bersih yang telah dilakukan diantaranya adalah kerjasama dengan Caritas Australia dan AUSAID program CLTS di 11 Desa dari 5 kecamatan di Kabupaten Pandeglang, kerjasama program CLTS dengan Project Concern International (PCI) di 3 Kecamatan di Kabupaten Pandeglang, kerjasama dengan instansi pemerintah Dinas Kesehatan untuk menyusun buku putih sanitasi dll.

Adapun, jika digambarkan secara sederhana, maka strategi yang dilakukan LAZ Harfa adalah sebagai berikut:

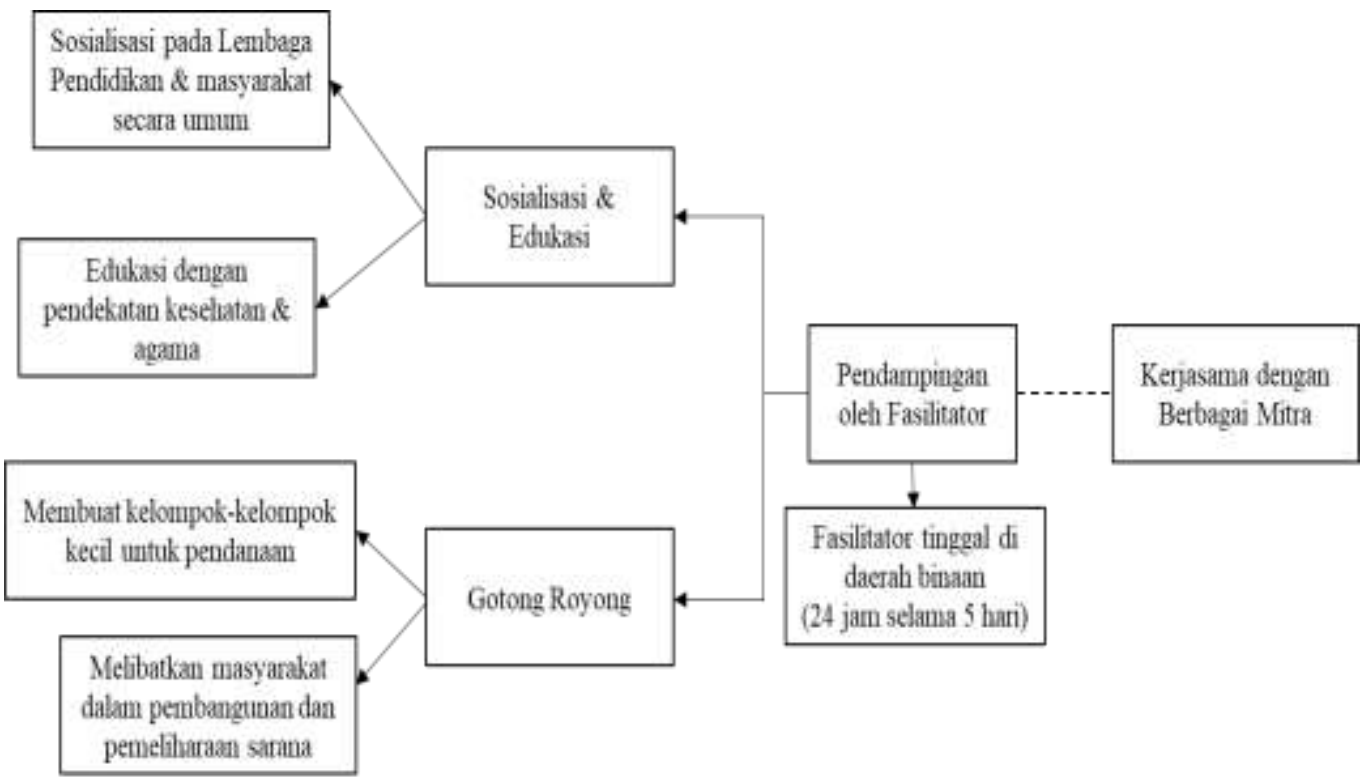

Gambar 2 Strategi Program Sanitasi dan Air Bersih LAZ Harfa

Sumber: Diolah Penulis

Terdapat peran yang cukup sentral pada strategi yang diterapkan oleh LAZ Harfa, yaitu dengan adanya fasilitator pendamping yang fokus ditempatkan di desa atau daerah sasaran program. Pentingnya peran fasilitator tersebut sejalan dengan penelitian Chaerunnisa 
(2014) bahwa salah satu yang menjadi faktor dalam meningkatkan partisipasi masyarakat desa terkait sanitasi dan air bersih adalah adanya peran kader kesehatan desa atau fasilitator.

Fasilitator LAZ Harfa juga telah menerapkan pendampingan sosial yang berpusat pada empat bidang tugas atau fungsi atau disebut juga 4P (Pemungkinan, Penguatan, Perlindungan dan Pendukungan). Dimana pemungkinan atau fasilitasi adalah fungsi yang berkaitan dengan pemberian motivasi dan kesempatan bagi masyarakat, penguatan adalah fungsi yang berkaitan dengan pelatihan atau pendidikan, perlindungan berkaitan dengan tugas fasilitator sebagai konsultan dan pendukungan yang berkaitan dengan keterampilan yang bersifat praktis (Suharto, 2015).

Strategi yang diterapkan oleh LAZ Harfa tersebut terbukti efektif dalam mengubah pola perilaku masyarakat dalam hal sanitasi dan air bersih yang keberlanjutan. Strategi yang diterapkan oleh LAZ Harfa juga sesuai dengan pernyataan UNICEF (2016) bahwa salah satu prasyarat mendasar untuk keberlanjutan jangka panjang dalam memperbaiki kondisi sanitasi dan air bersih adalah dengan membangun kerangka kerja yang akuntabilitas serta kuat dalam mekanisme programnya. Selain itu, perlu dibangunnya hubungan serta rasa tanggungjawab yang kuat antar sasaran atau pelaku utama dalam ini pelaku sanitasi dan air bersih.

Yacoob (1985) dalam penelitiannya menjelaskan bahwa penggunaan nilai-nilai dan struktur kepercayaan komunitas yang ada untuk mengubah perilaku dalam praktik sanitasi dan air bersih sangat diperlukan. Artinya bahwa penggunaan nilai-nilai agama dapat membantu dalam mempromosikan sanitasi dan air bersih.

Pada dasarnya program LAZ Harfa terkait sanitasi dan air bersih merupakan program yang berbentuk sebagai program pemberdayaan masyarakat. Walau dalam program tersebut LAZ Harfa berhasil memberdayakan masyarakat untuk meningkatkan sanitasi dan air bersih tanpa mengeluarkan dana sedikitpun, namun LAZ Harfa juga menyalurkan bantuan berupa pendayagunaan ZISWAF untuk sanitasi dan air bersih. Pendayagunaan ZISWAF untuk sanitasi dan air bersih di Indonesia diperbolehkan berdasarkan fatwa Majelis Ulama Indonesia (MUI) Nomor:001/MUNAS-IX/MUI/2015. Dimana dalam fatwa tersebut disebutkan bahwa bolehnya mendayagunakan ziswaf untuk sanitasi dan air bersih dengan ketentuan bahwa tidak terdapat kebutuhan mendesak bagi para mustahiq (untuk zakat) serta manfaat dari pembangunan sarana tersebut diperuntukkan bagi kepentingan umum.

Program-program LAZ Harfa yang berbentuk pendayagunaan ZISWAF untuk sanitasi dan air bersih diantaranya adalah program kerjasama dengan mitra misalnya kerjasama LAZ Harfa dengan Ikatan Dokter Indonesia (IDI) Pandeglang dalam program wakaf sumur, kerjasama bantuan sarana air bersih dengan Lazis PLN, kerjasama dengan Laznas BSM dalam program bedah rumah dan sarana air bersih dll.

Dengan demikian, LAZ Harfa mempunyai peran yang strategis dalam meningkatkan kesehatan masyarakat sebagai bentuk upaya dalam meningkatkan kesejahteraan masyarakat, dimana kesehatan mempunyai peranan yang sangat penting dalam kesejahteraan masyarakat.

\section{Simpulan}

Keberhasilan LAZ Harfa dalam meningkatkan akses sanitasi dan air bersih masyarakat Pandeglang membuktikan bahwa Lembaga Amil Zakat mempunyai peranan yang cukup strategis dalam meningkatkan kesejahteraan masyarakat tidak hanya di bidang ekonomi, namun juga bidang lainnya seperti kesehatan lingkungan. Hal tersebut juga 
menunjukan bahwa Lembaga Amil Zakat dapat berperan dalam mencapai SDGs, dimana akses sanitasi dan air bersih juga merupakan salah satu tujuan dalam SDGs.

Adapun strategi terkait program sanitasi dan air bersih yang dilakukan oleh LAZ Harfa adalah menitikberatkan pada edukasi masyarakat, melibatkan masyarakat secara langsung sehingga tumbuh kepedulian antar sesama masyarakat yang kemudian dapat membentuk kebiasaan gotong royong antar masyarakat. Selain itu, strategi yang tidak kalah pentingnya adalah melakukan pendampingan yang optimal oleh fasilitator serta menjalin kerjasama dengan berbagai mitra.

Adanya penelitian ini diharapkan dapat dijadikan sebagai rujukan bagi banyak pihak yang berkaitan seperti pemerintah serta lembaga lainnya dalam menyusun strategi terkait program untuk sanitasi dan air bersih. Selain itu, praktisi khususnya Lembaga Amil Zakat yang lainnya perlu juga mempunyai program pendayagunaan ziswaf untuk sanitasi dan air bersih agar masyarakat yang membutuhkan dapat merasakan manfaat dana ziswaf secara meluas dan berkelanjutan dengan meningkatnya akses sanitasi dan air bersih. Disamping itu, Lembaga Amil Zakat dapat menggunakan penelitian ini sebagai gambaran terkait strategi dalam melaksanakan programnya. Penelitian ini juga diharapkan dapat dijadikan sebagai referensi penelitian selanjutnya. 


\section{DAFTAR PUSTAKA}

Al Qur'an dan Terjemah. (2015). Departemen Agama RI. Bandung: CV Darus Sunnah

Chaerunnisa, C. (2014). Partisipasi Masyarakat dalam Program Penyediaan Air Minum dan Sanitasi Berbasisi Masyarakat (PAMSIMAS) di Kabupaten Brebes. POLITIKA, 5(2).

Chaniago, S. A. (2014). Perumusan Manajemen Strategi Pemberdayaan Zakat. Jurnal Hukum Islam, 12(1), 87-101.

Cronin, A. A., Sebayang, S. K., Torlesse, H., \& Nandy, R. (2016). Association of Safe Disposal of Child Feces and Reported Diarrhea in Indonesia : Need for Stronger Focus on a Neglected Risk. International Journal of Environtmental Research and Public Health. https://doi.org/10.3390/ijerph13030310

Fink, G., Ghunter, I., \& Hill, K. (2011). The effect of water and sanitation on child health : evidence from the demographic and health surveys 1986 - 2007. International Journal of Epidemiology, 40(June 2011), 1196-1204. https://doi.org/10.1093/ije/dyr102

Israul, H., \& Hera, S. (2018). Does water and sanitation effects on children' s physical development? Evidence from Indonesia Family life Survey ( IFLS ) 2014. E3S Web of Conferences, 09007. https://doi.org/https://doi.org/10.1051/e3sconf/20187409007

Kustanto, D. N. (2015). The Impact of Drinking Water Acces and Sanitation to Walfare Improvement. Jurnal Sosek Pekerjaan Umum, Vol.7 No.3, November 2015, Hal 173 - 179, 173180.

Lapid, D. G. (2012). Sustainable Sanitation in the Philippine Context. Water Practice \& Technology, 7(1). https://doi.org/10.2166/wpt.2012.024

Mara, D., Lane, J., Scott, B., \& Trouba, D. (2010). Sanitation and Health. PLoS Medicine, 7(11). https://doi.org/10.1371/journal.pmed.1000363

Otsuka, Y., Agestika, L., Sintawardani, N., \& Yamauchi, T. (2019). Risk Factors for Undernutrition and Diarrhea Prevalence in an Urban Slum in Indonesia: Focus on Water, Sanitation, and Hygiene. The American Society of Tropical Medicine and Hygiene, 100(3), 727-732. https://doi.org/10.4269/ajtmh.18-0063

Prabowo, H., Huda, M., Trimaya, L., \& Cronin, A. A. (2016). Air, Kebersihan, Sanitasi dan Kesehatan Lingkungan menurut Agama Islam. Sekolah Pascasarjana Universitas Nasional.

Riahi, M., Mohammadi, A. A., Moghadam, V. K., Robati, Z. S., \& Bidkhori, M. (2018). Diarrhea deaths in children among countries with different levels of the human development index. ScienceDirect, 17, 954-960. https://doi.org/10.1016/j.dib.2018.02.019

Rizki, B., \& Saleh, S. (2007). Keterkaitan Akses Sanitasi dan Tingkat Kemiskinan: Studi Kasus di Propinsi Jawa Tengah. Ekonomi Pembangunan Kajian Ekonomi Negara Berkembang, 12(3), 223-233.

Syafiq, A. (2016). Urgensi Peningkatan Akuntabilitas Lembaga Pengelola Zakat. ZISWAF, 3(1).

Suharto, Edi. (2005).Membangun Masyarakat, Memberdayakan Rakyat; Kajian Strategis Pembangunan Kesejahteraan Sosial dan Pekerjaan Sosial.Refika Aditama. 9793304391.

UNICEF. (2016). Strategy for Water, Sanitation and Hygiene 2016-2030. New York.

Utami, S., \& Handayani, S. K. (2017). Ketersediaan Air Bersih untuk Kesehatan dalam Pencegahan Diare pada Anak. In Optimalisasi Peran Sains dan Teknologi untuk Mewujudkan Smart City. Universitas Terbuka, Tangerang Selata (pp. 211-236).

Wardiha, M. W., \& Putri, P. S. A. (2018). Analisis Faktor-Faktor Yang Berpengaruh terhadap Penyediaan Fasilitas Air Bersih dan Sanitasi dengan System Interrelationship Model ( Studi 
Kasus: 12 Permukiman Tradisional di Provinsi NTB dan NTT). Seminar Nasional: Pengelolaan Air Bersih Dan Sanitasi Menuju Akses Universal Tahun 2019, ITB, (October).

Wiradifa, R., \& Saharuddin, D. (2017). Strategi Pendistribusian Zakat, Infak, Dan Sedekah (ZIS ) Di Badan Amil. At-Tijary Jurnal Ekonomi Dan Bisnis Islam, 3(1), 1-13. https://doi.org/10.21093/at.v3i1.937

Yacoob, M. (1985). Communicating Fundamentals of Water and Sanitation in Moslem Communities. Journal of Religion and Health, 24(4), 287-293.

Sumber internet:

Prasetya, Dwi. (2017). Miris, warga Provinsi Banten masih banyak yang BAB Sembarangan. https://www.merdeka.com/peristiwa/miris-warga-provinsi-banten-masih-banyak-yang-babsembarangan.html. Diakses pada 4 Desember 2019. 